\title{
Public radio and the problem of demographic change. The presenters' perspective on senior citizens' well-being factors in Polish Radio programmes
}

\author{
1. \\ Grażyna Stachyra \\ ORCID: 0000-0002-6396-112X
}

UNIVERSITY OF MARIA CURIE-SKLODOWSKA IN LUBLIN, POLAND

DOI: 10.19195/1899-5101.11.2(21).6

\begin{abstract}
Poland is an ageing society, a fact that has social repercussions. Government programmes point to the necessity of improving the quality of life of senior citizens in various domains. An important objective in gerontology is to increase the activity of senior citizens, which renders ageing a less arduous process. This objective has been postulated to involve the media. Given its public service remit and the specificity of audial communication, which enables a non-stereotypical treatment of old age, Polish Radio is tasked with including in its programming issues concerning the social inclusion of senior citizens. The aim of this study is to test the hypothesis that presenters of public radio, broadly accessible and popular among senior citizens as it is, address their well-being in its regular programmes.
\end{abstract}

KEYWORDS: demographics, public radio, social inclusion, senior citizens, well-being, audial communication.

\section{INTRODUCTION}

Demographic forecasts indicate that the proportion of elderly people in Polish society will continue to increase (GUS, 2014, p. 125). In the literature, the formal threshold of old age is usually placed at 60 (WHO) or 65 (UN, Eurostat) years of age. The Central Statistical Office of Poland (GUS) predicts that in 2040, more than every third Pole is going to be aged 60 or more, with more than four out of ten Poles likely to belong to that group in 2050 (GUS, 2014, p. 126). At the same time, a "democratisation of old age" can be said to be taking place, with a growing part of the population living long enough to reach this stage of life. (Annex to Resolution No. 238 of the Council of Ministers of 24th December 2013 (item 118), Monitor Polski, 2014, p. 8). The ageing of society is a problem to be tackled at state level. The implications of this process need to be investigated, in particular those that have 
a bearing on the well-being of senior citizens. In an interdisciplinary approach, well-being means broadly defined welfare, and the happiness of an individual; it is connected to the hierarchy of values, goals, life aspirations of an individual, or social groups, but is also viewed through the filter of indices such as the social norms defining its quality, the system of values, and the rules of social life. Therefore, the well-being of senior citizens is not merely their personal problem, but also a social one, and so one that falls within the remit of state institutions. The Government Programme for the Social Participation of Senior Citizens for 2014-2020, just like its earlier versions for the years 2012-2013, lists the following areas and directions of support that enable an improved well-being of the elderly: education; social activity; social participation; and social services for senior citizens (Abramowska-Kmon, 2011, p. 138). These are areas that need to be institutionally mediated to help shape the relations between senior citizens and the rest of society, and between senior citizens themselves. This mediation should ideally take place in conditions optimal for senior citizens, or ones that ensure the comfort of learning, the choice of activity or type of social participation. It is difficult to conceive of a better institutional mediator than radio, especially since, according to CBOS surveys, as many as $82 \%$ of persons aged 60 or older listen to radio (Omyła-Rudzka, 2016b, p. 3). Thus, by mediatising the lived reality of senior citizens' lives and their relations, radio can fulfil an important role in their lives. Since it operates in the medium of sound, it can work to prevent the formation of stereotypes and the discrimination of people based on their appearance. This is particularly important, since media representations of old age are instrumental in shaping attitudes towards it. By allowing the listener to focus on the sound of a person speaking, it allows the perception of the (verbal) contents rather than the (physical) form. Ignoring the physical appearance, it affords a comfortable on-air presence for those who may find their own physicality unattractive.

\section{HYPOTHESIS AND THE AIM OF RESEARCH}

Radio can play an important role in the lives of senior citizens by touching upon important issues and shaping the attitudes of the elderly towards the reality. Given the ongoing process of the ageing of society, a key challenge is to promote the activity of senior citizens so that they retain high levels of functioning and independence for as long as possible. Radio, as a medium popular among senior citizens, can be an ally in attaining this objective.

The most important factor is the rationale for including public radio in particular in this study. Its public service mission means its activity has a relational aspect, which means that interactions with listeners have a deeply humanistic character. Communication in public radio has the hallmarks of deeper contact (although the need to supplement licence fee revenue with advertising is forcing Polish Radio to introduce forms of contact with listeners aimed at maximising its marketing potential). First and foremost, however, Polish Radio, with its over 90 years of history, 
has accompanied listeners the longest and as such is the most strongly fixed in their perception, which implies an interest in its programming offer among the older generation. Besides, only the broadcasters selected for quantitative analysis dedicated their programmes to seniors by $(\mathrm{S})$ mark in their financial and programming plans. It allows us to include in this research the most representative programmes and examine in surveys their hosts as not randomly selected, but really experienced in this topic. The surveys were collected during September and October 2017 among the presenters from chosen stations.

The hypothesis of the research is that public radio programmes dedicated to senior citizens include topics that are important for their well-being. The research examines radio presenters' opinions about the presence of well-being factors in programmes which they host. Because of preliminary character of this study, the first concern is to show whether radio discusses seniors' well-being factors at all.

The main hypothesis concerns a key issue in gerontology, the well-being of senior citizens. The concept of well-being is directly connected with the psychological sphere of a person. It is gauged by whether a person's needs are being met, where the needs are existential ("to be"), related to security ("to have"), or social ("to love and be loved”) (Baumann, 2006, p. 166). The notion of well-being dates back to the midtwentieth century and originally was interpreted as a good life in the sense of material status. However, the quality of life is also affected by cultural, social, and economic determinants, one's education, or one's expectations. Well-being is closely related to the motivation of a person to fulfil their needs: the higher the fulfilment of important needs, the better the well-being (Kieszkowska-Grudy et al., 2014, p. 63).

A sense of well-being, especially the perceived satisfaction from one's own life, can be affected by the objective living conditions of the person doing the self-assessment, as well as from the real level of his or her ability and fitness; the person's subjective belief in his or her own capabilities; his or her outlook on life. (Diener et al., 2004, pp. 35-50)

The indicators of well-being were chosen from a thorough study by Katarzyna Bauman (2006, p. 169). The survey conducted in this research includes a whole list of components concerning the physical, emotional, and intellectual functioning, life satisfaction, economic status, the perception of health, vitality, energy, and ways of spending free time.

\section{STATE OF RESEARCH}

To date, the features of radio programming targeting senior citizens or its impact on their quality of life in Poland have not been researched. The extensive "Social Diagnosis", a survey conducted biannually, does include internet, telephone communications, the press, and television in the chapter "Technologies and the media in the homes and lives of Poles". Radio, notwithstanding its 90 years of history, is not discussed in the survey beyond the brief reference in the statement "we do not 
analyse the audience of radio, which is popular chiefly among older listeners" (Czapiński \& Panek, 2015, p. 372); it should be noted, however, that the report does outline consumers aged 65 and older in the context of their use of other media. Research on the media representations of old age focuses on the press, television, and internet, while radio is consistently glossed over (Skrzypaczek \& Chorobik, 2011). The journal Gerontologia Polska [Polish Gerontology] has not devoted any of its issues to a discussion of the use of radio among senior citizens. Development strategies of the media market treat radio in a cursory manner, mostly in the context of forecasting audience figures. While analyses of longer timeframes conducted by the Polish National Broadcasting Council between 2001 and 2010 have shown a decrease in the time spent listening to radio in all age groups, this decrease has been the lowest among the elderly. The prognoses of the future of radio in the years to come remain optimistic: "traditional electronic media (...) remain competitive (...) radio is not losing listeners" (Romaniuk, 2014). Existing reports do not elaborate on the question of senior citizens and radio (Dziomdziora, 2017, p. 27). Similarly, the monograph Seniorzy w świecie nowych technologii. Implikacje dla praktyki edukacyjnej oraz rozwoju społeczeństwa informacyjnego [Senior citizens in the world of new technologies. Implications for educational practice and the development of the information society], (Tomczyk \& Wąsiński, 2013) does not contain analyses of radio.

Single examples of publications in English do exist, and include the article And how old are you?: Age reference as an interpretative device in radio counselling (Thell \& Jacobsson, 2016, pp. 31-43), which reveals the cultural roots of problems in the dialogue with the elderly and the influence of these problems on therapeutic actions undertaken in radio programming, as well as giving an account of qualitative research informed by conversation analysis. The impact of radio on the everyday lived experience of the elderly is outlined in Pertti Alasuutari's study Why Does the Radio Go Unnoticed? (1997, pp. 161-172). Stachyra and Jędrzejewski investigate social inclusion in the Polish Radio programme "Studenci Trzeciego Wieku" [Students of the Third Age] in their article The image of the aged on Polish Radio. Towards social inclusion (2014, pp. 27-33). They give the example of the programme "Studenci Trzeciego Wieku" broadcast on Polish Radio One in 2011. The programme was the sequel to a cult television series Czterdziestolatek [Forty-Something], which was originally going to be continued on television. However, the story of older people, as well as actors well past 50, did not prove popular with the decision-makers and was cancelled after one season. "I heard on the TV that they do not need old people,' explained the director and screenwriter of the sequel, Jerzy Gruza” (Superseriale, 2012).

\section{THE EXCLUSION OF SENIOR CITIZENSS AS A SOCIAL PROBLEM, AND THE ROLE OF RADIO IN ITS PREVENTION}

The above-mentioned Government Programme for Social Participation of Senior Citizens for 2014-2020 as well as any local initiatives (Rządowy program, 2017) 
seek to improve the social inclusion of elderly people. The joint report by the Commission and Council of the $\mathrm{EU}$ on social inclusion states it is

a process which ensures that those at risk of poverty and social exclusion gain the opportunities and resources necessary to participate fully in economic, social, and cultural life and to enjoy a standard of living and well-being that is considered normal in the society in which they live. It ensures that they have greater participation in decision making which affects their lives and access to fundamental rights. (Council of the EU, 2004, p. 8)

Social inclusion is inextricably connected with its opposite, social exclusion, coined in the 1970s to describe "the porousness of the French system of social security (...) the term made its way to the discourse of social sciences, replacing the classical term "social marginalisation «" (Frieske, 2008, pp. 20-21). It is important to note cultural elements as factors that contribute to discrediting certain individuals within the social structure of modern societies (Grotowska-Leder, 2005). Dynamicity and a processual character are key features of the mechanisms of social exclusion, or the isolation - whether voluntary or enforced by circumstances - of individuals or social groups from the community and institutions of the contemporary state (Jarosz, 2008). "Exclusion can concern work, consumption, or participation in culture, the life of local communities, and politics" (Czapiński \& Panek, 2016, p. 378).

Recent research confirms that Polish senior citizens can be considered to be threatened by exclusion. As many as $32 \%$ of the respondents notice discrimination against elderly people in the street, in a shop, or on public transport. About onefifth (21\%) of those questioned have noted less than good treatment of senior citizens in the health service, and every eighth person questioned (12\%) has noticed such treatment in offices or banks (Omyła-Rudzka, 2016a, pp. 4-5). But it is not only discriminatory treatment that can result in exclusion. Senior citizens often find it difficult to cope with everyday activities. Sixty-four per cent of persons aged 60 or more need support when visiting a doctor, an office, or a bank. As many as $50 \%$ would expect support and advice in important issues; an even higher percentage, 58\%, are not coping with running a single-person household (Bożewicz, 2016, p. 5). Only one in eight sixty-year-olds and older who were questioned declares being in paid employment, a fact that contributes to the alienation of this age group from the broader community. Among the respondents aged 61 to 65 , almost a quarter are in paid employment, compared with $7 \%$ among those aged $66-74$, and as few as $4 \%$ in the oldest group (Omyła-Rudzka, 2016a, p. 2). At the same time, senior citizens have a keen interest in politics. Twenty per cent of 60 to 65-year-olds, $27 \%$ of those aged 66 to 74 , and $21 \%$ of those aged 75 or more follow political events closely, proportions which are several percentage points higher than among any group below 59 years of age (Kalka, 2016, p. 12). Similarly, election turnouts confirm that senior citizens are a group that actively supports their favoured candidates, thereby influencing the shape of democracy in the country. 
Thus, on the one hand senior citizens are a community important for the functioning of the state; on the other, however, they are struggling with everyday problems, feeling marginalised and underestimated, often treated as inferior and incapable. Part of the answer as to the source of such attitudes is the high mediation of contemporary reality. Depending on the channel, this process has a substantial impact on what image of the world individuals form, and the way the media is used informs how communities influence each other.

Research conducted over 10 years ago (Donlon \& Ashaman, 2005, pp. 307-319) shows a strong correlation between time spent by senior citizens on watching television and negative perceptions of old age. Visual media in particular contribute to stereotyping of old age, which can be conducive to social exclusion of senior citizens. The stereotype as "a schema representing a group or kind of persons distinguished by an easily noted characteristic that defines their social identity" (Wojciszke, 2002, p. 68) is also "a mental representation of the world, and as such has a bearing on what information on the members of various groups a person seeks, and what information that person notices and remembers. It also has an impact on that person's social actions" (Stangor \& Schaller, 1999, p. 15). The contemporary human being seeks answers chiefly in the media, which in turn impose the limits of perception on its audiences, as "the world appears different to different people, depending on what map the media have drawn for them" (Pratkanis, 2003, p. 78). At the same time, this "map" has little detail as far as senior citizens are concerned. "Old age in the media practically does not exist" (Skrzypaczek \& Chorobik, 2011, p. 17). "[The elderly G.S] are constantly absent from the symbolic sphere. The cult of the body, beauty, and youth appears to be responsible - images of old people do not fit the dominant messages" (Jakubowska et al., 2009, p. 91). Therefore, what remains a valid problem is to use the media in a way that, on the one hand, will enable the presence therein of senior citizens, and on the other, will allow them to improve their well-being, especially since the media, including new media, are already present in their lives. Opinion polls show that the elderly particularly enjoy radio.

Senior citizens combine the use of the internet with recourse to other media, that is, while browsing the internet they tend to listen to radio or watch television. This may be related to the fact that for this age group, television and radio remain the most important sources of information. (Szmigielska et al., 2012, p. 145)

CBOS surveys have shown that over $80 \%$ of senior citizens in Poland see radio as a companion in their free time (Omyła-Rudzka, 2016b, p. 3). This is important in finding ways of socialising this demographic, as radio can provide "a window to the world". It may sound trite, but the role of the radio really is invaluable. It can draw a map and an image of the world thanks to mediating human relations. It can prevent the stereotyping of old age due to its audial nature, which facilitates the directing of attention to words and their value, and which can represent the speak- 
er as authoritative rather than as a visually unattractive elderly person. This shift of emphasis from image to sound counteracts an automatic perception of an old person as aesthetically unappealing and as such an uninteresting participant of media discourse.

Though it targets numerous viewers, visual consumer culture has not shaped distinct models of beauty for the different stages of life, focusing only on that based on the logic of youth. The example given above of television rejecting the subject of old age indicates a serious social problem that is ageism, or "the systematic process of stereotyping of and discrimination against persons on the grounds of their old age" (Palmore, 1990, p. 116). The image of the elderly is impacted by existing stereotypes of old age as a stage of life, as well as of stereotypes pertinent to qualities and behaviours of elderly people. Some believe these stereotypes inform attitudes towards senior citizens (Schmidt \& Boland, 2010, p. 116). The image of the elderly hinges on what information has been conveyed about them. "If information comes directly from the elderly person, this image is more positive; if it is given indirectly, that is by means of communications coming from other persons, the image depends on the contents of these communications (evaluated as positive, negative, or neutral)" (Szarota, 2002, p. 120). Therefore, the representations of the elderly in the media have an impact on how these persons are perceived by society. Research conducted over ten years ago shows that senior citizens were the key target group primarily for television advertisers from the pharmaceutical and cosmetic industries (Pawlina, 2010). That the images of elderly people are used so rarely in advertising indicates that this stage of life has not been perceived as particularly attractive (Ziębińska, 2007, p. 120). Recent research notes a pro-age trend in television advertising, with the slogan "beauty has no age" (Ginter, 2013, p. 55). Therefore, the issues at play include not just stereotyping, but the ways in which the public space is mediated.

Why, then, does radio "accept" old and "aesthetically unappealing" protagonists? The primary reason is its audial character, which allows the listeners to focus solely on the sonic parameters of a person's image. Perception is not visually distracted, and so the audial message is perceived as richer, diverse, and comprising multiple elements: we hear sighs and changes in tempo; we catch the tone of irony or sarcasm; we are more attentive emotionally. A radio programme is also decoded through the listener's own sensitivity: it is not perceived via the filter of an image that would also be a ready-made representation of a phenomenon, requiring no activity on the part of the audience.

Another reason why radio is comfortable with "ugly" characters is its aptitude for following dominant trends in natural interpersonal communication: "We all like stories, especially when they help us understand - or at least interpret everyday events. A mirror like this, one in which we can see ourselves and a reflection of our own acts, motives, and mistakes - along with their consequences - is something that helps us learn much faster" (McLeish, 2007, p. 272). 
In oral cultures, old persons (the sage, the bard) had the mandate to speak in public. Having lived longer and seen more, they were expected to know more and pass on that knowledge. This was an experience of certain images transcending both space (such as relating war stories from faraway places) and time (such as building an opinion based on experiences from different stages of life). This was also an instance of exclusive privilege, as old age was the surest way of accruing the baggage of what one has experienced (and seen). At present, the older speaker is perceived as much less authoritative, a change which derives from easy access to numerous communications (including archival ones) that compress temporal relations, and from the facility of experiencing visual messages from even the most distant corners of the world, which compress spatial relations.

As opposed to television, however, radio has retained the original schema of the initiation into knowledge: the story. Radio genres that have elements of storytelling (radio plays, radio documentaries, novellas) allow the perception of the flow of words without involving the sense of sight. There is no distracting image, so the listener is more focused on the flow of words, on the logical accents, on the prosodic strategies. A pause is not a production mistake or an unexpected pause in transmission, but carries an emotional load, builds tension, has a soothing function, or simply allows a "breath", protecting from information overload; the speaker's intonation allows the melody of the language to show, making listening pleasurable.

Recent research shows that the stations most popular with older listeners include three nationwide stations: Polish Radio 1, Radio Maryja, and Polish Radio 2; two stations covering more than one region: TOK FM and RMF Classic; and regional public radio stations (Trochimczuk, 2016, p. 11). The character of public radio broadcasting is shaped by its diverse programming, which includes the classic genres of the radio play, reportage, or the radio soap opera; the use of extensive archival material and its integration into current work; promoting programmes with a long history (the radio soap operas "W Jezioranach" (In Jeziorany) or "Matysiakowie" ("The Matysiak Family"), broadcast on Polish Radio for over 50 years); on-air charity drives, showing the pro-social attitude of the radio; the attention given across all genres to linguistic correctness and enunciation (as regards word stress and intonation). Public radio, compelled by law to fulfil the remit of public service, has an obligation to offer diverse programming. The Broadcasting Act currently in force in Poland does not precisely define the remit of public service, but it does specify in what actions it should be realised. The most important ones include

providing (...) the entire society and its individual groups with diversified programme services and other services in the area of information, journalism, culture, entertainment, education, and sports which shall be pluralistic, impartial, well-balanced, independent, and innovative, marked by high quality and integrity of broadcast. (KRRiT, 1992, Art. 21) 
Public radio therefore should provide an environment conducive to conversation and exchange of views. Radio can educate, enhance the competence of senior citizens in performing everyday tasks, teach online communication, debunk stereotypes, make listeners more active, invite them to co-host programmes, stress the role of elderly people as mentors to the young, advance neighbourliness, and promote the benefits of Universities of the Third Age (UTAs).

\section{METHODOLOGY}

The broadcasters selected for quantitative analysis were those Polish Radio broadcasting stations (Auditorium 17 Radio Group) which specify their target audience as seniors (S) in their financial and programming plans. Only seven stations have such programmes, which invites the question of why so few of them do, since regional Polish Radio stations - given their remit - should be particularly attentive to the problem of an ageing society. These are the regional stations of Polish Radio which broadcast not only from every city which is the seat of their respective voivodship, but also use transmitters in smaller towns to reach listeners across the voivodships. Altogether, Auditorium 17 Radio Group stations have at their disposal a total of 92 terrestrial FM transmitters, so that they cover not only the voivodship they are located in but also parts of neighbouring ones. The combined range of Auditorium 17 transmitters therefore covers listeners in all of Poland.

Because this is a preliminary study, our first concern is to establish whether radio discusses the well-being of senior citizens at all. This was done by means of surveys conducted among the hosts of programmes dedicated to the elderly: Piękne $\dot{z} y c i e$ [The Beautiful Life] Radio Lublin, Równe szanse 60+ [Equal Opportunities 60+] Radio Koszalin, Aktywni 60+ [Active 60+] Radio PiK, Kwadrans starszaka [Oldie's Quarter] Radio Merkury Poznań, Czas Seniorów [Seniors' Time] Radio Łódź, Czuję się młodo [I Feel Young] Radio Kraków, and Kiedy nadchodzi jesień $\dot{z} y c i a$ [In the Autumn of Our Lives] Radio Rzeszów. All are recurrent programmes.

From an economic standpoint, well-being is measured with recourse to a number of quantifiable indices, with the so-called basket of goods and services, social minimum, level of consumption, the scope of basic needs, or social services or benefits (Baumann, 2006, pp. 168-170). These were addressed in the survey conducted among hosts of programmes targeting senior citizens.

The survey consisted of the following questions:

1. In your programme, do you discuss issues relevant to the physical well-being of senior citizens?

The respondents were asked to assign values between 1 and 5 (least to most frequently discussed) to the following: energy and functioning, sexuality, quality of health care, lack of pain, command of senses (eyesight, hearing), sufficient time for rest and sleep. 
2. In your programme, do you discuss issues relevant to the personal well-being of senior citizens?

The respondents were asked to assign values between 1 and 5 (least to most frequently discussed) to the following: mental health, happiness, self-esteem, dignity, identity, continued personal development, self-image/appearance, memory, control over one's own life, independence, spirituality, freedom from stress, love, education, ease of adaptation, freedom of choice.

3. In your programme, do you discuss issues relevant to the financial well-being of senior citizens?

The respondents were asked to assign values between 1 and 3 (least to most frequently discussed) to the following: financial independence, security, diverse sources of income, possession of property (such as a flat or a car).

4. In your programme, do you discuss issues relevant to the social well-being of senior citizens?

The respondents were asked to assign values between 1 and 3 (least to most frequently discussed) to the following: family, friendship, rich social life, support network.

5. In your programme, do you discuss issues relevant to the life satisfaction of senior citizens?

The respondents were asked to assign values between 1 and 3 (least to most frequently discussed) to the following: reminiscence, fulfilment, living life to the full, creativity, cheerfulness.

6. In your programme, do you discuss issues relevant to the awareness of the purpose of life among senior citizens?

The respondents were asked to assign values between 1 and 3 (least to most frequently discussed) to the following: altruism, being involved, participation in the lives of others; a productive, fruitful ageing process.

7. In your programme, do you discuss issues relevant to the aesthetic well-being of senior citizens?

The respondents were asked to assign values between 1 and 3 (least to most frequently discussed) to the following: free time, interests and hobbies, contact with music/art/literature.

8. In your programme, do you discuss issues relevant to the spirituality of senior citizens?

The respondents were asked to answer Yes or No.

9. In your programme, do you discuss issues relevant to the end of life of senior citizens?

The respondents were asked to assign values between 1 and 3 (least to most frequently discussed) to the following: a good death, a sense of control, the quality of care (minimising pain and suffering).

10. In your programme, do you discuss issues relevant to the joy of senior citizens? 
The respondents were asked to answer Yes or No to two specific questions: a) pleasures large and small (food, travel), b) fun, entertainment.

11. In your programme, do you discuss issues relevant to the moral well-being of senior citizens?

The respondents were asked to answer Yes or No.

\section{RESULTS}

The concept of well-being is described in the literature as multi-dimensional due to its complexity and internal connections (Brzezińska et al., 2002, pp. 103-126). Analysing it, one has to consider physical, material, social, and emotional well-being, as well as satisfaction from a person's own productivity (the research hypotheses relate to these areas). The definition of well-being foregrounds the subjective assessment of life as a whole or its components, such as social contacts or the satisfactions from tasks performed. The following factors affecting the well-being of persons in late adulthood have been noted: their physical, emotional, intellectual, and social functioning; life satisfaction; perception of health; economic status; sexual functioning; vitality; energy; ways of spending free time (questions on whether subjects related to these factors are discussed in radio programmes will be included in surveys for quantitative research).

The responses to the survey give a good idea of issues relevant to well-being which are discussed in Polish Radio programmes targeting the elderly. A detailed analysis of the results follows below.

In your programme, do you discuss issues relevant to the physical well-being of senior citizens?

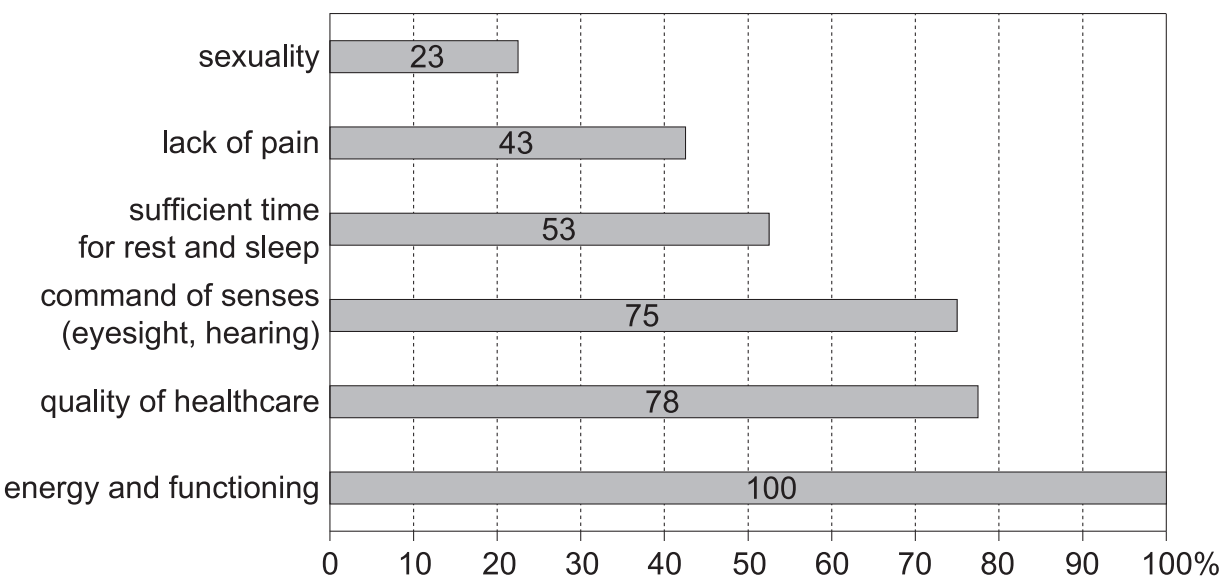

Figure 1. The physical well-being of senior citizens in the subjects of Polish Radio programmes Source: Author. 
The above percentages have been obtained by weighted arithmetic means of scores for each issue. They indicate that the key problem for all programmes is the energy and satisfactory functioning of elderly people (100\% weighted score), with issues related to the quality of healthcare (78\%) and the command of senses (75\%) following closely behind. Slightly less important were the issues of rest (53\%) and the experience of pain or lack thereof (43\%). Sexuality of senior citizens was the least frequently raised issue (23\%).

In your programme, do you discuss issues relevant to the personal well-being of senior citizens?

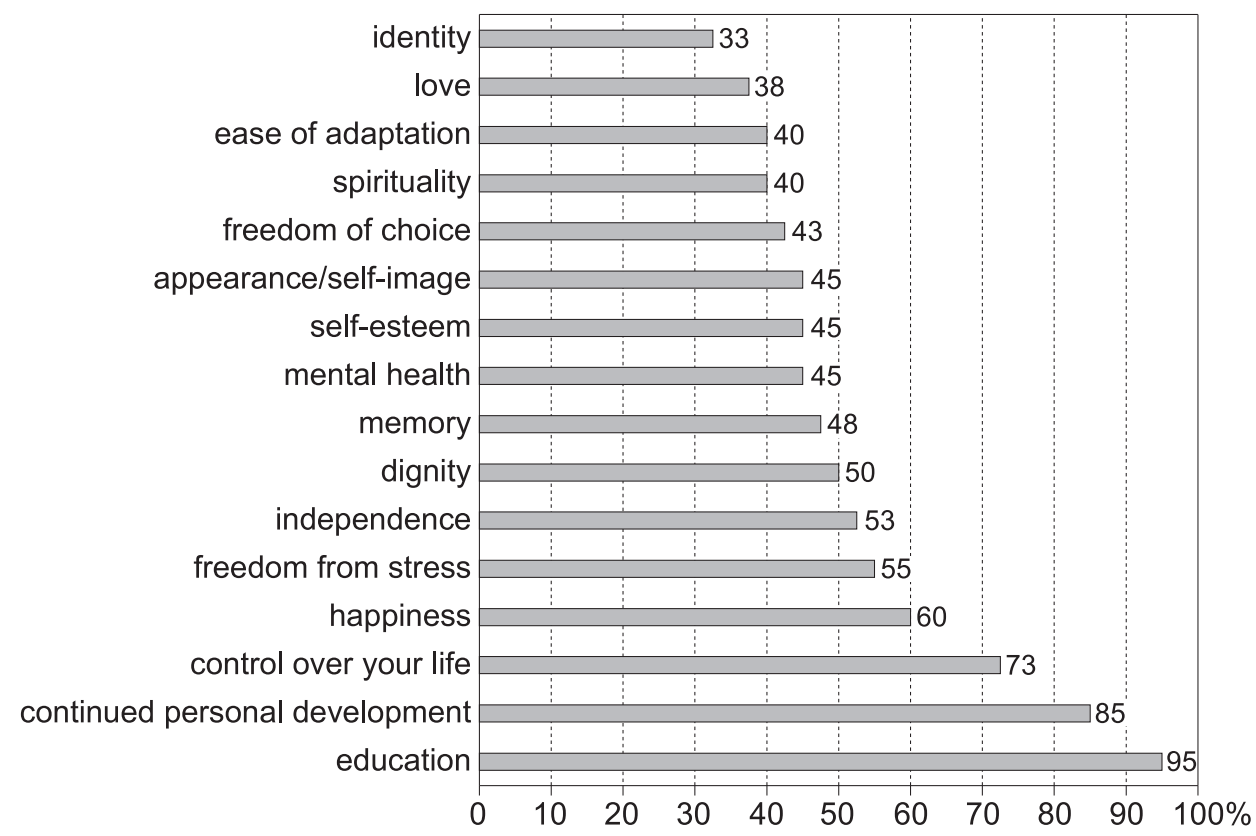

Figure 2. Personal welfare of senior citizens in the subjects of Polish Radio programmes Source: Author.

Among issues relevant to the personal well-being of senior citizens, education and continued personal development appear to be prioritised by broadcasters, with respective scores of $95 \%$ and $85 \%$. Control over one's life (73\%) is another important issue. Happiness has a score of $60 \%$, while, at $40-55 \%$, most of the remaining issues appear to have a similar level of importance. The issues of love and those related to identity rank slightly below, at $38 \%$ and $33 \%$ respectively.

The bar charts below show the distribution of answers given by programme hosts in eight Polish Radio stations; the vertical chart values correspond respectively to: 3 - very frequently, 2 - frequently, 1 - sometimes, 0 - never.

Financial independence is discussed very frequently in the programmes of the four of the surveyed radio stations, and two discuss it only sometimes. 
In your programme, do you discuss issues relevant to the financial well-being of senior citizens?

3 - very frequently, 2 - frequently, 1 - sometimes, 0 - never

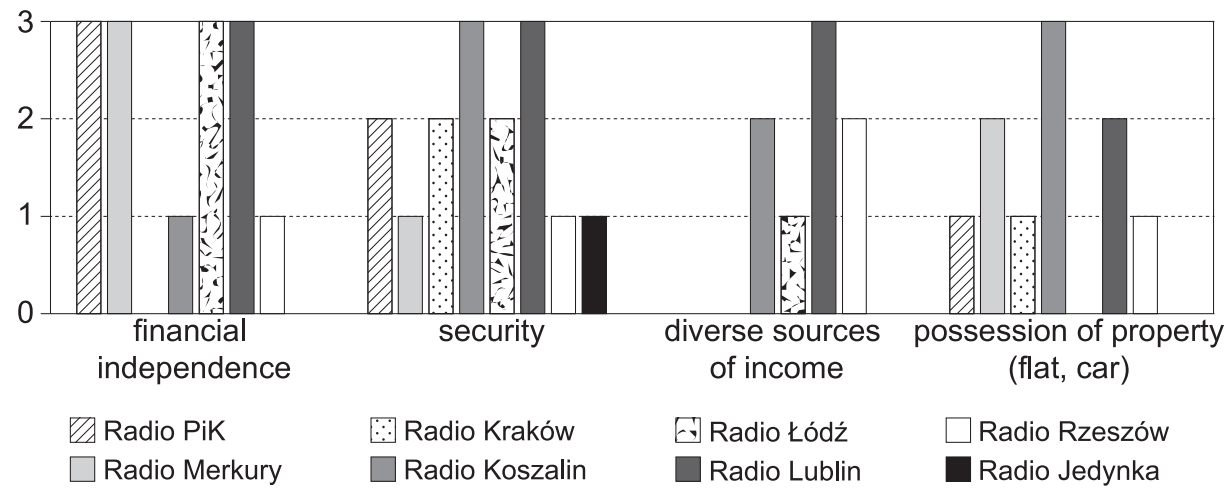

Figure 3. The financial well-being of senior citizens in the subjects of Polish Radio programmes

Source: Author.

Financial security is an issue that recurs very frequently in the programming of two of the surveyed radio stations, often in three of the radio stations in question, while three other stations discuss it sometimes.

Possession of property is brought up very frequently in one of the radio stations surveyed, frequently in two, and sometimes in three of the stations.

Diversified sources of income is discussed very frequently in one radio station, frequently in two others, and sometimes in one of the radio stations surveyed.

In your programme, do you discuss issues relevant to the social well-being of senior citizens?

3 - very frequently, 2 - frequently, 1 - sometimes, 0 - never

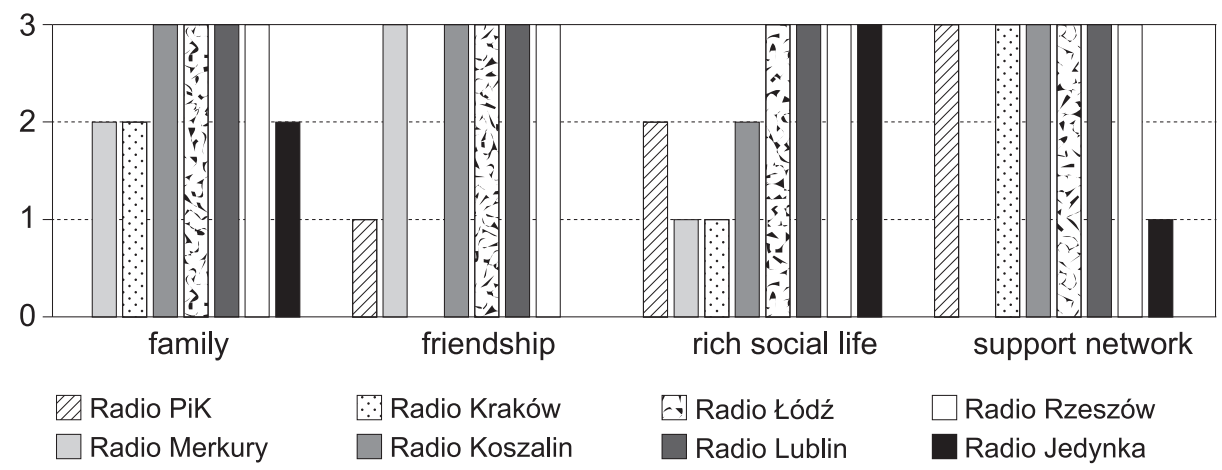

Figure 4. The social well-being of senior citizens in subjects of Polish Radio programmes Source: Author. 
The chart shows that essentially all the factors of social well-being are present in the programming analysed. The most frequently discussed issue is that of the support network, indicated by as many as six broadcasters as something very frequently present in their programmes. Friendship was described as very frequently discussed in five stations, and issues of family and a rich social life in four.

In your programme, do you discuss issues relevant to the life satisfaction of senior citizens?

3 - very frequently, 2 - frequently, 1 - sometimes, 0 - never

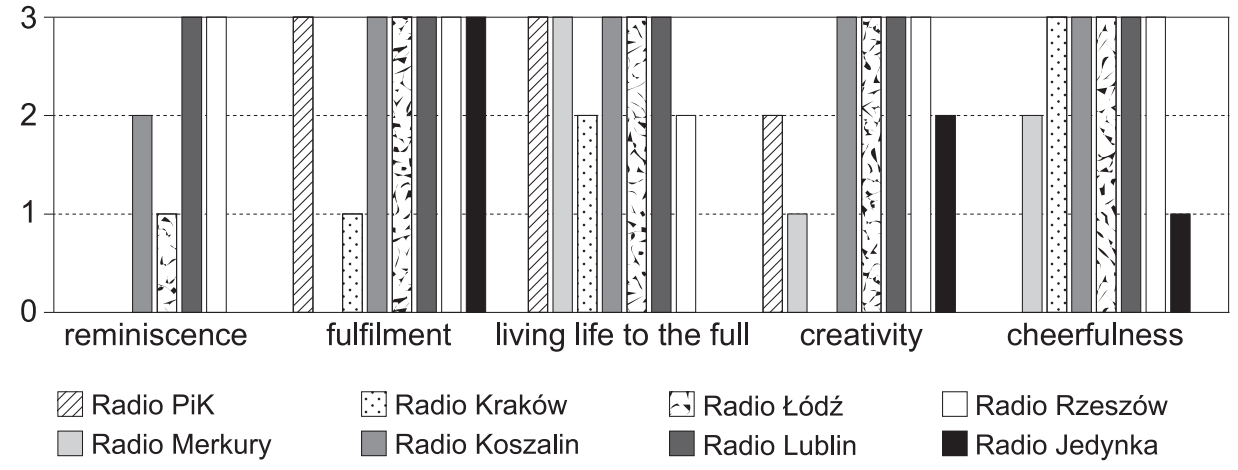

Figure 5. Life satisfaction of senior citizens in subjects of Polish Radio programmes

Source: Author.

In your programme, do you discuss issues relevant to the awareness of the purpose of life among senior citizens?

3 - very frequently, 2 - frequently, 1 - sometimes, 0 - never

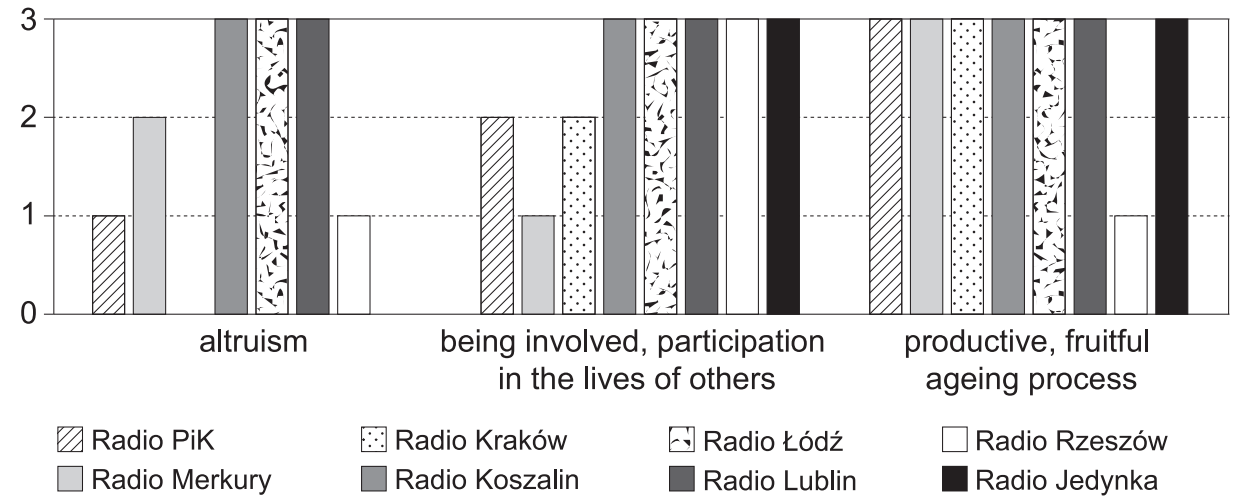

Figure 6. The awareness of the purpose of life in the subjects of Polish Radio programmes Source: Author. 
Among issues pertinent to life satisfaction, the most typically referenced ones are fulfilment (indicated as a very frequent subject in six radio stations), living a full life, and cheerfulness (indicated as such in five).

Among the three determinants of well-being relevant to the awareness of life purpose, productive ageing is the most prevalent issue, indicated by as many as seven broadcasters as very frequently present in programmes. Involvement and participation in the lives of others is the second most frequently indicated subject, followed by altruism.

In addition, the question about the moral well-being of senior citizens (Question 11 in the survey) received $100 \%$ affirmative answers, indicating a strong presence of this subject in the programmes surveyed.

In your programme, do you discuss issues relevant to the aesthetic well-being of senior citizens?

3 - very frequently, 2 - frequently, 1 - sometimes, 0 - never
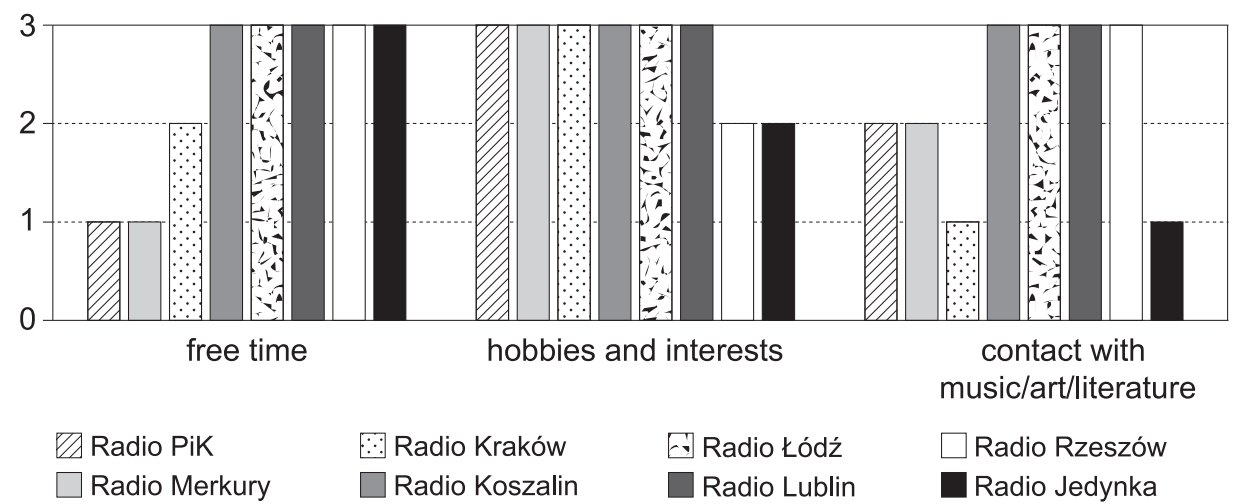

Figure 7. The aesthetic well-being of senior citizens in the subjects of Polish Radio programmes

Source: Author.

Issues pertinent to the aesthetic well-being of senior citizens are referenced very frequently. In particular, this concerns hobbies and interests (indicated six times as "discussed very frequently" and twice as "frequently"), followed by free time (described five times as "discussed very frequently" and once as "frequently") and contact with art (referenced "very frequently" four times and "frequently" by one station).

Moreover, questions on the presence of joy in the lives of elderly people, both in terms of pleasures large and small and fun/amusement, received $100 \%$ affirmative answers.

Interestingly, issues concerning death and the final stages of life are raised much less frequently than those relevant to the joy of life. The quality of care of elderly persons was twice described as referenced "very often" and three times as "often", 
In your programme, do you discuss issues relevant to the end of life of senior citizens?

3 - very frequently, 2 - frequently, 1 - sometimes, $0-$ never
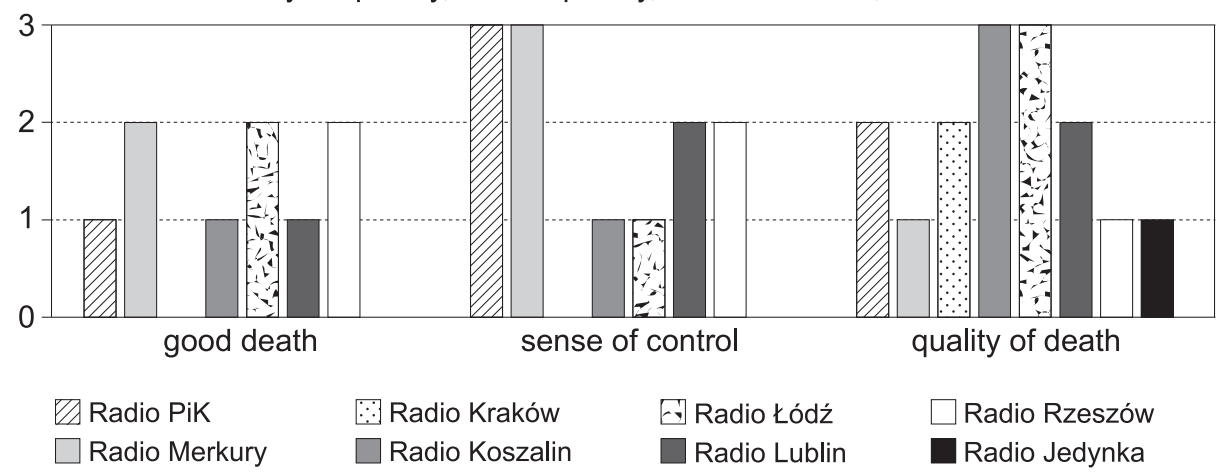

Figure 8. End-of-life issues in the subjects of Polish Radio programmes

Source: Author.

a sense of control was ranked by two radio stations as raised "very frequently" and by two more as "frequently", while a good death was brought up "frequently" in three.

Question 8 concerning the presence of issues pertinent to the spirituality of the elderly received $100 \%$ affirmative answers, while question 11 on the moral well-being of senior citizens was answered in the affirmative in $75 \%$ of cases.

\section{CONCLUSIONS AND PROPOSALS FOR FURTHER RESEARCH}

The analyses above show that in programmes dedicated to senior citizens, the presenters' opinion on all components of well-being are frequently discussed in Polish Radio. The responses to the survey indicate that programming targeting the elderly can be described as "inclusive", or promoting social inclusion, addressing their personal preferences and needs (such as those concerning continued personal development and education or ways of spending free time) rather than focusing on ways of exclusion. The programmes can be said to mobilise and activate senior citizens, or can be described as addressing those persons who continue to experience and foster the need for activity. These features of well-being indicated by presenters in their programmes appear as important to them. A key principle of gerontology is to preserve one's independence as long as possible. This is achieved by maintaining a good physical and mental condition related to undertaking physical and mental effort, and by preserving social connections. It also entails a new way of thinking about old age as a time which is restful, interesting, and attractive. All aspects of this problem were shown as discussed by hosts of programmes dedicated to the elderly. The hypothesis of the research that public radio programmes dedicated to senior citizens include topics that are important for their well-being was confirmed. 
A survey verified the statement that public radio is well-positioned to encourage the activity of senior citizens by devoting the broadcast to the condition of successful ageing or reaching old age "with the avoidance of disease and disability, the maintenance of high physical and cognitive function, and sustained engagement in social and productive activities" (Rowe \& Kahn, 1997, p. 433), which impacts on the well-being of senior citizens. As a medium popular with the elderly, and one obliged to fulfil a public service mission, Polish Radio is interested in playing the role of an ally in achieving this key objective. The answer to the fundamental question, whether radio is meeting its potential by touching upon issues relevant to the well-being of senior citizens is positive from the presenters' perspective. This opinion of the programmes' hosts is the most important at the start of the research because the decision to talk about certain issues usually comes from the presenter.

The subsequent stages of this study should therefore establish whether senior citizens use the contents of radio programmes to educate themselves on how to sustain the correct level of psychophysical development; whether radio programmes help senior citizens sustain their social activity and make use of organisations representing their interests; whether senior citizens are inspired by radio programmes to appreciate the value of and nurture the relations within their community and between generations; finally, whether broadcasters are aware of the importance of the form and the contents of their message, which is to influence the actions they undertake to improve the well-being of senior citizens.

A content and discourse analysis of radio programmes, would enable us to establish the ways the medium (here, radio) is utilised and their impact on a community (here, senior citizens). We would be able to assess how senior citizens perceive the contents of the programmes and the way the relations with broadcasters are formed, and whether this form of mediatisation is conducive to enhancing their well-being. We could also ascertain the attitudes of journalists who host the programmes and explore their experiences in contacts with the elderly. Questions concerning the subjective perception of the way relations are formed and the impact of audial contents in programmes for senior citizens would be included in partly structured in-depth interviews with programme hosts and with the most active participants of the programmes, as indicated by the hosts.

Qualitative analysis would be focused on the assessment by senior citizens of programme contents in fields relevant to improving the quality of life as indicated by the Government Programme for Social Participation of Senior Citizens for 20142020. These are: education of the elderly, social activity, actions to improve the participation of senior citizens in public life, and social care services for senior citizens.

The qualitative analysis would be complemented by a quantitative study conducted via CATI (Computer Assisted Telephone Interview). The research would be conducted on individuals who declare that they listen to one of the Polish Radio stations (One, Two, Three, or Polish Radio 24) or a regional Polish Radio station and are between 60 and 75 years of age. 
The next stage of the study should be an examination of relations and actions undertaken by senior citizens as a result of radio programmes. This is particularly important in light of the most recent research concerning the activity of senior citizens in Poland: groups of senior citizens that spend their time in similar ways were established with recourse to k-means clustering. The first and the third cluster each comprised $38 \%$ of the subjects aged 60 or over, while the second cluster accounted for $24 \%$ (Omyła-Rudzka, 2016b, pp. 8-11). Particularly interesting are the differences between the senior citizens analysed as part of the first and second cluster, since they evince very divergent attitudes. As many as $38 \%$ of senior citizens in the first cluster show very low levels of activity, do not read books or newspapers, do not meet friends or acquaintances; almost two-thirds of persons in this cluster (64\%) feel that the best part of their lives has now passed. The second cluster is comprised by the most active senior citizens. They engage in almost all kinds of activities listed in the survey more frequently than other senior citizens. The ways of spending free time which are particularly distinctive for this group are: use of computers and internet, participation in culture (cinema, theatre, opera, museums, concerts), doing sports, travelling across Poland, Europe, and the world, continued education, participation in various courses and learning foreign languages. These activities are undertaken much more frequently by seniors in this cluster than by others. Most of the persons in this group (59\%) have an optimistic outlook of the future, believing they have yet to experience many good things.

This divergence indicates the need to take action (including by the media) aimed at popularising the ways of increasing the physical and mental well-being of senior citizens and of increasing their social involvement, also by institutions representing them.

\section{REFERENCES}

Alasuutari, P. (1997). Why does the radio go unnoticed?. The Nordicom Review of Nordic Research on Media and Communication, a Special issue on Radio Research in Denmark, no 1, pp. 161-172.

American National Research Council (2001). Preparing for an Aging World. The Case for CrossNational Research. Washington D.C.: National Academy Press, pp. 34-43.

Argyle, M. (2004). Przyczyny i korelaty szczęścia. In: W. J. Czapiński (ed.), Psychologia pozytywna. Nauka o szczęściu, zdrowiu, sile i cnotach człowieka. Warszawa: Wydawnictwo Naukowe PWN, pp. 165-203.

Baumann, K. (2006). Jakość życia w okresie późnej dorosłości - dyskurs teoretyczny. Gerontologia Polska, Vol. 14, no 4, p. 166.

Bożewicz, M. (2016). Jakiej pomocy potrzebuja osoby starsze i kto jej im udziela. CBOS Komunikat $\mathrm{z}$ badań, no 162. Retrieved on 8 February, 2016 from https://www.cbos.pl/SPISKOM.POL/2016/ K_162_16.PDF.

Brzezińska A., Stolarska M., \& Zielińska J. (2002). Poczucie jakości życia w okresie dorosłości. In: K. Appelt, J. Wojciechowska (eds.), Zadania i role społeczne w okresie dorosłości. Poznań: Wydawnictwo Fundacji Humaniora, pp. 103-126.

Chyła, W. (1998). Technologicznie zapośredniczona (medialna) przestrzeń publiczna: ponowoczesna maszyna rządzenia bez ludzi. In: J. S. Wojciechowski \& A. Zeidler-Janiszewska (eds.), Formy estetyzacji przestrzeni publicznej. Warszawa: Druk Inter Graf, pp. 25-40. 
Council of the EU (2004). Joint Report by the Commission and the Council on Social Inclusion. Retrieved on 15 March, 2017 from http://ec.europa.eu/employment_social/soc-prot/soc-incl/ final_joint_inclusion_report_2003_en.pdf.

Czapiński, J., \& Panek, T. (eds.) (2015). Diagnoza społeczna 2015. Warunki i jakość życia Polaków. Raport. Warszawa: Rada Monitoringu Społecznego, pp. 355-372.

Diener E., Suh E. M., Lucas R. E., \& Smith H. L. (1999). Subjective well-being: Three decades of progress. Psycholical Bulletin, Vol. 125, no 2, pp. 276-302.

Donlon, M., Ashaman, O., \& Levy, B. R. (2005). Creating a defense against television's ageism. Journal of Social Issues, Vol. 61, pp. 307-319.

Dziomdziora, W. (2017). Strategia rozwoju rynku medialnego w Polsce 2015-2020. Warszawa. Retrieved on 13 March, 2017 from http://sztukamediafilm.pl/wp-content/uploads/2014/09/SMFStrategia-rozwoju-rynku-medialnego-w-Polsce-2015-2020.pdf.

Frieske, K. W. (1999). Marginalność społeczna. In: H. Domański et al. (eds.), Encyklopedia socjologii, Vol. 2. Warszawa: Oficyna Naukowa, pp. 167-171.

Frieske, K. W. (ed.) (2004), Utopie inkluzji. Sukcesy i porażki programów reintegracji społecznej. Warszawa: IPiSS.

Frieske, K. W. (2008). Społeczna marginalność jako koszt systemowy. In: M. Jarosz (ed.), Wykluczeni. Wymiar społeczny, materialny i etniczny. Warszawa: Instytut Studiów Politycznych PAN, pp. 20-21.

Ginter, J. (2013). Językowy obraz starości i starzenia się w reklamie telewizyjnej. Gdańsk: Wydawnictwo Uniwersytetu Gdańskiego.

Grotowska-Leder, J., \& Faliszek, K. (eds.). (2005). Ekskluzja i inkluzja społeczna: diagnoza, uwarunkowania, kierunki działań. Toruń: Wydawnictwo Edukacyjne Akapit.

Gryglewska, B. (2006). Prewencja gerontologiczna. In: T. Grodzicki, J. Kocemba \& A. Skalska (eds.), Geriatria z elementami gerontologii ogólnej. Gdańsk: Via Medica, pp. 47-52.

GUS (2014). Prognoza ludności na lata 2014-2050. Studia i Analizy Statystyczne. Warszawa.

Hepp, A., \& Hasebrink, U. (2013). Human Interaction and Communicative Figurations. The Transformation of Mediatized Cultures and Societies. Communicative Figurations. Working Paper, no. 2. Retrieved on 20 July, 2017 from http://www.kommunikative-figurationen.de/fileadmin/ redak_kofi/Arbeitspapiere/CoFi_EWP_No-2_Hepp_Hasebrink.pdf.

Jakubowska, H., Racinlewska, A., \& Rogowski, K. (2009). Patrząc na starość. Kultura wizualna starości. Poznań: Wydawnictwo Naukowe UAM.

Jarosz, M. (ed.) (2008). Wykluczeni. Wymiar społeczny, materialny i etniczny. Warszawa: Instytut Studiów Politycznych PAN.

Kalka, J. (2016). Portret społeczno-demograficzny seniorów. CBOS Komunikat z badań, no. 160. Retrieved on 8 February, 2016 from https://www.google.pl/?gws_rd=ssl\#q=J.+Kalka,+Portret+spo $\%$ C5\%82eczno-demograficzny+senior\%C3\%B3w,+CBOS+Komunikat+z+bada\%C5\%84,+ $\mathrm{nr}+160 / 2016$.

Kieszkowska-Grudny, A., Maliszewska, J., Siwy- Hudowska, A., \& Nawrocki, S. (2014). Ocena jakości życia i strategii radzenia sobie z chorobą w grupie chorych poddanych zabiegowi endoprotezoplastyki stawu biodrowego. Gerontologia Polska, 2, p. 63.

KRRiT (2012), Przemiany w zwyczajach stuchania radia w latach 2001-2010. Warszawa. Retrieved on 20 July, 2017 from http://www.krrit.gov.pl/Data/Files/_public/Portals/0/kontrola/program/ radio/problemowe/zwyczaje_radio_2001-2010.pdf.

Lisowska-Magdziarz, M. (2008). Media powszednie: środki komunikowania masowego i szerokie paradygmaty medialne w życiu codziennym Polaków u progu XXI wieku. Kraków: Wydawnictwo Uniwersytetu Jagiellońskiego.

McLeish, R. (2007). Produkcja radiowa. Kraków: Wydawnictwo Uniwersytetu Jagiellońskiego.

Nowak, J. (ed.) (2008). Meandry wykluczenia społecznego. Warszawa: Komandor. 
Omyła-Rudzka, M. (2016a). Czy osoby starsze sa w naszym społeczeństwie dyskryminowane? CBOS Komunikat z badań, no 164. Retrieved on 8 February, 2016 from http://www.cbos.pl/SPISKOM. POL/2016/K_161_16.PDF

Omyła-Rudzka, M. (2016b). Sposoby spędzania czasu przez seniorów. CBOS Komunikat z badań, no 163. Retrieved on 8 February, 2017 from http://www.cbos.pl/SPISKOM.POL/2016/K_163_16.PDF.

Palmore E. B. (1990). Ageism: Negative and Positive. New York: Springer Publishing Company.

Pawlina, A. (2010). Sposoby prezentowania osób starszych w reklamie. Analiza wybranych zagadnień. Zeszyty Naukowe Wyższej Szkoły Ekonomicznej w Bochni, 8, pp. 99-115.

Pratkanis, A., \& Aronson, E. (2003). Wiek propagandy. Używanie i nadużywanie perswazji na co dzień. Warszawa: Wydawnictwo Naukowe PWN.

Romaniuk, A. (2014). Radio ma się dobrze - krótkie sprawozdanie z I kwartału 2014 r. Warszawa: Komitet Badań Radiowych. Retrieved on 4 April, 2017 from http://www.radiotrack.pl/index. php/kbr/aktualnoci-kbr/ 142-radio-ma-si-dobrze.html.

Rządowy Program na rzecz Aktywności Społecznej Osób Starszych na lata 2014-2020. Retrieved on 21 July, 2017 from http://www.mpips.gov.pl/seniorzyaktywne-starzenie/zalozenia-dlugofalowejpolityki-senioralnej-w-polsce-na-lata-20142020/.

Rowe, J. W., \& Kahn, R. L. (1997). Successful aging. The Gerontologist, 37(4), pp. 433-440.

Schmidt D. F., \& Boland, S. M. (1968). Structure of perceptions of older adults: Evidence for multiple stereotypes. Psychology and Aging, 3, p. 116.

Shingler, M., \& Wieringa, C. (1998). On Air. Methods and Meanings of Radio. London-New York-Sydney: Arnold.

Skrzypaczek, J., \& Chorobik, M. (eds.) (2011). Przestrzenie seniorów. Codzienne oblicza i medialne kreacje starości. Kraków: Wydawnictwo AGH.

Stachyra. G., \& Jędrzejewski, S. (2014). The image of the aged in the Polish radio. Towardss social inclusion. In: I. Carpentier Reifova \& T. Pavlickova (eds.), Media, Power and Empowerment. Central and Eastern European Communication and Media Conference CEECOM. Cambridge: Cambridge Scholars Publishing, pp. 27-33.

Stangor, Ch., \& Schaller, M. (1999). Stereotypy jako reprezentacje indywidualne i zbiorowe. In: C. N. Macrae, Ch. Stangor \& M. Hewstone (eds.), Stereotypy i uprzedzenia. Najnowsze ujęcie. Gdańsk: Gdańskie Wydawnictwo Psychologiczne, pp. 13-36.

Superseriale (2012). Retrieved on 12 April, 2012 from http://superseriale.se.pl/seriale/powstajenowy-czterdziestolatek-ale-tylko-w-radiu_210630.html.

Szarota, Z. (2002). Percepcja starości wśród studentów. Rocznik Komisji Nauk Pedagogicznych PAN, Vol. 55, pp. 129-146.

Szmigielska, B., Bąk, A., \& Hołda, M. (2012). Seniorzy jako użytkownicy Internetu. Nauka, 2, p. 145.

Thell, N., \& Jacobsson, K. (2016). “And how old are you?": Age reference as an interpretative device in radio counselling. Journal of Aging Studies, Vol. 39, pp. 31-43.

Tomczyk, L., \& Wąsiński, A. (eds.) (2013). Seniorzy w świecie nowych technologii. Implikacje dla praktyki edukacyjnej oraz rozwoju społeczeństwa informacyjnego. Biblioteka Gerontologii Społecznej, 1-2, pp. 5-269.

Trochimczuk, M. (2017), Wskaźniki słuchalności i audytorium programów radiowych w 2016 r. Warszawa. Retrieved on 20 July, 2017 from http://www.krrit.gov.pl/Data/Files/_public/Portals/0/ kontrola/program/radio/kwartalne/rynek_radiowy2016.pdf.

Ustawa z dnia 29 grudnia 1992 r. o Radiofonii i Telewizji, Dz.U. 1993 Nr 7, poz. 34, rozdz. 4, art. 21, 31-32.

Welsch, W. (2005). Estetyka poza estetyką. Kraków: Towarzystwo Autorów i Wydawców Prac Naukowych Universitas.

Wojciszke, B. (2002). Człowiek wśród ludzi. Zarys psychologii społecznej. Warszawa: Scholar.

Załącznik do uchwały nr 238 Rady Ministrów z dnia 24 grudnia 2013 r. (poz. 118), Monitor Polski, 2014.

Ziębińska, B. (2010). Uniwersytety Trzeciego Wieku jako instytucje przeciwdziałajace marginalizacji osób starszych. Katowice: Śląsk. 